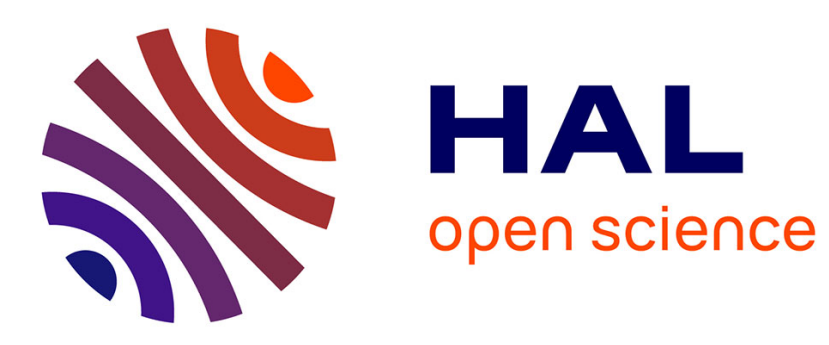

\title{
Stabilization of polynuclear plutonium(IV) species by humic acid
}

Remi Marsac, Nidhu Lal Banik, Christian M. Marquardt, Jens Volker Kratz

\section{To cite this version:}

Remi Marsac, Nidhu Lal Banik, Christian M. Marquardt, Jens Volker Kratz. Stabilization of polynuclear plutonium(IV) species by humic acid. Geochimica et Cosmochimica Acta, 2014, 131, pp.290 300. 10.1016/j.gca.2014.01.039 . hal-01904152

\section{HAL Id: hal-01904152 https://hal.science/hal-01904152}

Submitted on 24 Oct 2018

HAL is a multi-disciplinary open access archive for the deposit and dissemination of scientific research documents, whether they are published or not. The documents may come from teaching and research institutions in France or abroad, or from public or private research centers.
L'archive ouverte pluridisciplinaire HAL, est destinée au dépôt et à la diffusion de documents scientifiques de niveau recherche, publiés ou non, émanant des établissements d'enseignement et de recherche français ou étrangers, des laboratoires publics ou privés. 
Stabilization of polynuclear plutonium(IV) species

36

\section{by humic acid}

${ }^{a}$ Institute for Nuclear Waste Disposal, Karlsruhe Institute of Technology, P.O. Box 3640, D-76021

Karlsruhe, Germany

${ }^{b}$ Institute for Nuclear Chemistry, University of Mainz, 55099 Mainz, Germany

Rémi Marsac $^{\mathrm{a},{ }^{*}}$, Nidhu Lal Banik ${ }^{\mathrm{a}, \mathrm{b}}$, Christian Michael Marquardt ${ }^{\mathrm{a}}$, Jens Volker Kratz ${ }^{\mathrm{b}}$

*Corresponding author:

E-mail address: remi.marsac@kit.edu

Tel +4972160826064; Fax: +4972160823927 


\section{Abstract}

Although the formation of tetravalent plutonium $(\mathrm{Pu}(\mathrm{IV}))$ polymers with natural organic matter was previously observed by spectroscopy, there is no quantitative evidence of such reaction in batch experiments. In the present study, $\mathrm{Pu}(\mathrm{IV})$ interaction with humic acid (HA) was investigated at $\mathrm{pH} 1.8,2.5$ and 3 , as a function of HA concentration and for $\mathrm{Pu}$ total concentration equal to $6 \times 10^{-8} \mathrm{M}$. The finally measured $\mathrm{Pu}(\mathrm{IV})$ concentrations $\left([\mathrm{Pu}(\mathrm{IV})]_{\mathrm{aq}}\right)$ are below $\mathrm{Pu}(\mathrm{IV})$ solubility limit. $\mathrm{Pu}(\mathrm{IV})-\mathrm{HA}$ interaction can be explained by the complexation of $\mathrm{Pu}(\mathrm{IV})$ monomers by HA up to $[\mathrm{Pu}(\mathrm{IV})]_{\mathrm{aq}} \sim 10^{-8} \mathrm{M}$. However, the slope of the log-log $\mathrm{Pu}(\mathrm{IV})$-HA binding isotherm changes from $\sim 0.7$ to $\sim 3.5$ for higher $[\mathrm{Pu}(\mathrm{IV})]_{\mathrm{aq}}$ than $\sim 10^{-8} \mathrm{M}$ and at any $\mathrm{pH}$. This result suggests the stabilization of hydrolyzed polymeric $\mathrm{Pu}(\mathrm{IV})$ species by HA, with a 4:1 Pu:HA stoichiometry. This confirms, for the first time, previous observations made by spectroscopy in concentrated systems. The humic-ion binding model, Model VII, was introduced into the geochemical speciation program PHREEQC and was used to simulate $\mathrm{Pu}(\mathrm{IV})$ monomers binding to $\mathrm{HA}$. The simulations are consistent with other tetravalent actinides-HA binding data from literature. The stabilization of a $\mathrm{Pu}$ tetramer $\left(\mathrm{Pu}_{4}(\mathrm{OH})_{8}{ }^{8+}\right)$ by HA was proposed to illustrate the present experimental results for $[\mathrm{Pu}(\mathrm{IV})]_{\mathrm{aq}}$ $>10^{-8} \mathrm{M}$. Predictive simulations of $\mathrm{Pu}(\mathrm{IV})$ apparent solubility due to HA show that the chosen $\mathrm{Pu}(\mathrm{IV})$-polymer has no impact for $\mathrm{pH}>4$. However, the comparison between these predictions and recent spectroscopic results suggest that more hydrolyzed polymeric $\mathrm{Pu}(\mathrm{IV})$ species can be stabilized by $\mathrm{HA}$ at $\mathrm{pH}>4$. Polymeric $\mathrm{Pu}(\mathrm{IV})-\mathrm{HA}$ species might significantly enhance $\mathrm{Pu}(\mathrm{IV})$ apparent solubility due to humics, which support a colloid-facilitated transport of this low solubility element.

\section{Keywords}

Plutonium(IV), humic acid, complexation, polynuclear species, PHREEQC, Model VII. 
Humic colloids such as humic (HA) and fulvic (FA) acids are ubiquitous in natural waters and present a high binding capacity for dissolved metal ions. It has been evidenced that, in many cases, the mobility of metals in the environment was associated with colloidal transport (Kretzschmar et al., 2005). This is particularly the case for plutonium (Pu), a highly toxic and radioactive element. Significant amounts of $\mathrm{Pu}$ have been introduced into the environment by nuclear weapons tests, for instance. The aqueous chemistry of plutonium is rich and complex owing to its multitude of oxidation states ranging from +3 to +6 under environmental conditions. Among those, $\mathrm{Pu}(\mathrm{IV})$ exhibits the largest stability field and is considered as the most relevant oxidation state (Choppin, 2003). Although $\mathrm{Pu}(\mathrm{IV})$ was considered as rather immobile due to its extremely low solubility (approximately $10^{-11}-10^{-10}$ $\mathrm{M}$ at $\mathrm{pH}=7$; Neck and Kim, 2001), it shows a colloid-facilitated transport in presence of humic colloids. This behavior was shown in migration experiments of humic-rich ground water spiked with plutonium and other tetravalent metal ions like Th, Hf, and Zr (Artinger et al., 2003a, 2003b). Because of the strong interaction with humic colloids, the concentration of tetravalent trace metal ions in natural ground waters is directly related to the content of dissolved organic matter (DOC) (Artinger et al., 2003a). Because humic and fulvic acids are ubiquitous, they can play a significant role in the transport of plutonium to the biosphere wherever plutonium has been released: from final and intermediate repositories, by hazardous incident of nuclear power plants or facilities of the nuclear fuel cycle, or deposits from the atmosphere by atmospheric bomb tests and reentry of artificial satellites containing atomic batteries.

However, there are only a few experimental data about $\mathrm{Pu}(\mathrm{IV})-\mathrm{HA}$ complexation that can be used for geochemical and transport modeling to assess the hazard of plutonium for the biosphere. Thanks to the very similar chemical properties of the f-elements, it is possible, for 
a given redox state, to compare the stability constant with a ligand of different actinides (e.g. Th, U, Np, Pu). Reiller et al. (2008) reviewed all the available tetravalent actinide (An(IV)) complexation data with HA and found a high consistency between them. More recent $\mathrm{Pu}(\mathrm{IV})-$ HA binding studies are in relatively good agreement with the latter observation (Szabó et al., 2010; Sasaki et al., 2012). In these references, $\mathrm{Pu}(\mathrm{IV})-\mathrm{HA}$ interaction is described in terms of complexation of mononuclear $\mathrm{Pu}$ with humic acid. However, a recent X-ray absorption spectroscopic (XAFS) study has yielded evidence for the formation of polynuclear $\mathrm{Pu}(\mathrm{IV})$ species with HA (Dardenne et al., 2009). This study suggested the formation of small polynuclear species (i.e. a few $\mathrm{Pu}$ atoms) rather than large-sized $\mathrm{Pu}(\mathrm{IV})$-(hydr)oxide particles embedded in the organic matrix. Therefore, from the mechanistic point of view, it might be possible to consider these entities as polynuclear complexes with humic acid rather than precipitated nanophases stabilized in solution by organic polyelectrolytes.

An(IV) aquo ions have a high tendency to hydrolyse and to form amorphous hydroxide solids e.g. $\left(\mathrm{PuO}_{2(\mathrm{am}, \mathrm{hyd})}\right)$. In the presence of these amorphous solid $\mathrm{Pu}(\mathrm{IV})-$ (hydr)oxide, $\mathrm{Pu}(\mathrm{IV})$ can form eigen colloids $(>1-2 \mathrm{~nm}$ ) that can increase by two orders of magnitude the apparent solubility of plutonium (Neck et al., 2007). Furthermore, in acidic conditions, in the absence of solid (i.e. for solutions prepared below the saturation index of $\left.\mathrm{PuO}_{2 \text { (am,hyd) }}\right)$ it has been shown that $\mathrm{Th}(\mathrm{IV})$ and $\mathrm{Pu}(\mathrm{IV})$ aqueous speciation is controlled by small polynuclear species (i.e. smaller than $1 \mathrm{~nm}$ ) (Walther et al., 2008, 2009). Contrary to Th(IV), where well-defined species could be identified (i.e. from dimers to hexamers), $\mathrm{Pu}$ simultaneously forms species of great variety. Therefore, on the one hand, intrinsic chemical properties of $\mathrm{Pu}(\mathrm{IV})$ might explain why polynuclear species are formed with $\mathrm{HA}$. On the other hand, $\mathrm{Pu}(\mathrm{IV})$ eigen colloids might be stabilized by HA complexing groups. Indeed, it has been shown in the case of $\mathrm{Np}(\mathrm{IV})$ that small organic acids can stabilize polynuclear species (Takao et al., 2012), as well as in case of Pu(IV) with glycine (Knope and Soderholm, 2013). Earlier 
118 studies have also observed the formation of polynuclear cation-HA species. In case of Al(III),

119 Browne and Driscoll (1993) and Sutheimer and Cabaniss (1997) considered the formation of

120 Al dimers to explain their complexation data. In case of $\mathrm{Fe}(\mathrm{III})$, there are spectroscopic

121 evidences for the formation of Fe di- or trimers with HA (Gustafsson et al., 2007; Karlsson

122 and Persson, 2010), although there are few complexation studies evidencing the formation of

123 polynuclear cation-HA in batch experiment. It is interesting to note that trivalent $\mathrm{Al}$ and $\mathrm{Fe}$

124 present a high tendency to hydrolyze and to form polynuclear species in undersaturated

125 solutions with respect to solid phases (e.g. Hellman et al., 2006; Sarpola et al., 2013), as it is

126 the case for An(IV).

127 Although the stabilization of polynuclear $\mathrm{Pu}(\mathrm{IV})-\mathrm{HA}$ species was suggested by 128 spectroscopy and is mechanistically plausible, there is so far no quantification of such

129 reactions in batch experiments. Indeed, previous studies aimed at investigating the interaction

130 of mononuclear An(IV) with HA, and the formation of humic colloids consisting of small

131 polynuclear metal species and HA was not considered. In contrast to all above mentioned

132 studies, the present work aims at verifying the formation of polynuclear-Pu(IV)-HA species.

133 The experiments were performed under acidic conditions in order to be able to study their

134 interaction in a large range of final $\mathrm{Pu}(\mathrm{IV})$ aqueous concentrations by minimizing the

135 formation of particulate $\mathrm{Pu}(\mathrm{IV})$-(hydr)oxides or eigen colloids. A semi-mechanistical humic-

136 ion binding model (Model VII: Tipping et al., 2011) was introduced into the geochemical

137 speciation program PHREEQC (Parkhurst and Appelo, 1999) and was used as a tool to

138 discuss the relevance of polynuclear-Pu(IV)-HA species and their potential impact on $\mathrm{Pu}(\mathrm{IV})$

139 apparent solubility due to HA complexation under acidic to neutral $\mathrm{pH}$ conditions.

140

141 
All chemicals were of pro analytical quality or better and were obtained from Merck

144 (Darmstadt, Germany) or Riedel de Haen (Seelze, Germany). Milli-Q deionized water was

145 used to prepare the solutions. The $\mathrm{pH}$ was measured by a $\mathrm{pH}$ meter $(\varphi-310$, Beckman,

146 Germany) with a combined electrode (Beckman, Germany). The pH-meter was calibrated

147 daily with certified commercial buffers at $\mathrm{pH}=1, \mathrm{pH}=2, \mathrm{pH}=4, \mathrm{pH}=6$ (Merck, Darmstadt,

148 Germany).

\subsection{Plutonium solution}

For all the complexation studies, a $99.1 \mathrm{wt} \%{ }^{239} \mathrm{Pu}$ stock solution $\left(6.0 \times 10^{-4} \mathrm{M}\right)$, with small amounts of other isotopes $\left(0.888 \mathrm{wt} \%{ }^{240} \mathrm{Pu}, 0.014 \mathrm{wt} \%{ }^{241} \mathrm{Pu}\right)$ and known specific activities was used. The plutonium solution was prepared by diluting an aliquot of the stock solution with $1 \mathrm{M} \mathrm{HClO}_{4}$. The solution then consisted of different oxidation states of plutonium. The tetravalent oxidation state of $\mathrm{Pu}$ was obtained by potentiostatic electrolysis in $1 \mathrm{M} \mathrm{HClO}_{4}$. For the electrolysis, a homemade glass electrolytic cell with three separated compartments (U-shape) was used. The middle one was used as a working electrode (Pt), the right one contained a Pt counter electrode and the left one contained the reference electrode $(\mathrm{Ag} / \mathrm{AgCl})$. These compartments were connected with a potentiostat for obtaining a constant potential at the working electrode. A mixture of Pu oxidation sates was firstly electrolyzed at 0.6 Volt to obtain $\mathrm{Pu}(\mathrm{III})$, then $\mathrm{Pu}(\mathrm{IV})$ was fastly obtained from $\mathrm{Pu}(\mathrm{III})$ at 0.9 Volt. The purity

162 of the $\mathrm{Pu}(\mathrm{IV})$ oxidation state was controlled by UV-Vis spectrometry (Cohen 1961). About $16398 \%$ of $\mathrm{Pu}(\mathrm{IV})$ and $2 \%$ of $\mathrm{Pu}(\mathrm{IV})$ colloids were in the stock $\mathrm{Pu}$ solutions. The radioactivity 164 concentration of ${ }^{239} \mathrm{Pu}$ was measured by liquid scintillation counting (LSC) using the scintillation cocktail Ultima Gold XR (Packard) and LSC Tricab (Hewlett Packard). 


\subsection{Humic acid (HA)}

The commercially available Aldrich humic acid (AHA) (sodium salt, charge 37 no. 01816-054) was purified and isolated as described in (Kim and Buckau, 1988; Kim et al., 1990). The proton exchange capacity (PEC) is equal to $4.60 \times 10^{-3} \mathrm{eq}^{-1}$ (Kim and Buckau, 1988; Kim et al., 1990; Seibert et al., 2001). Although AHA is sometimes criticized as a weak model for humic substances, its ion-binding behavior is rather similar to those of other

173 humic substances (Avena et al., 1999; Milne et al., 2001, 2003; Saito et al., 2005; Pourret et al., 2007).

\subsection{Complexation experiments}

For the complexation experiments, $\mathrm{HA}$ and $\mathrm{Pu}(\mathrm{IV})$ were brought into contact at different $\mathrm{pH}$ values (1.8-3.0). The $\mathrm{pH}$ of the samples was adjusted by using a minimum of 0.1 $\mathrm{M} \mathrm{HClO}_{4}$ or $0.1 \mathrm{M} \mathrm{NaOH}$ solutions. The $\mathrm{Pu}(\mathrm{IV})$ concentration was $6.6 \times 10^{-8} \mathrm{M}$, and the humic acid content was varied between 0.01 and $25 \mathrm{mg} / \mathrm{L}$ and all mixtures were shaken continuously on an orbital shaker at $25^{\circ} \mathrm{C}$. All experiments were performed at $\mathrm{I}=0.1 \mathrm{M} \mathrm{NaClO}_{4}$ under aerobic condition at room temperature. Total sample volume was $10 \mathrm{~mL}$ in $20 \mathrm{~mL}$ vials. The samples were filtrated using ultrafiltration ( $1 \mathrm{kDa}$ pore size) after 24 hours, 3 days, 1 week, and 2 weeks during preliminary complexation experiments. This preliminary study indicated that complexation equilibrium was established after 1 week, so 1 week for sampling was chosen in subsequent complexation experiments. The free $\mathrm{Pu}$ ion concentration was

187 determined by liquid scintillation counting (LSC) of the filtrates. In absence of humic acid, 188 the sorption of $\mathrm{Pu}(\mathrm{IV})$ on the filter material as well as on the vessel was determined and 189 considered in the evaluations. In the case of humic acid, less than $5 \%$ of HA passed through 190 the $1 \mathrm{kDa}$ ultrafilter as measured by UV-Vis, which is being neglected in the present study.

191 Pourret et al. (2007) also investigated AHA complexation properties using 5kDa ultrafilter 
192

193

194

195

196

198

199

200

201

202

and also detected negligible amount of organic matter passing through the membrane by total organic carbon analysis. All experimental conditions and their results are given in the supporting information (Table S1).

\subsection{Complexation modeling using PHREEQC and Model VII}

The Humic Ion-Binding Model VII (Tipping et al., 2011) is an improved version of Model VI (Tipping, 1998). Both are based on the same equations but the total number of different cation binding sites required to describe HA heterogeneity is decreased in Model VII (= 50 versus 80 for Model VI). Model VI and VII are initially coupled with the inorganic speciation code WHAM. It is here coupled with PHREEQC (version 2) developed by Parkhurst and Appelo (1999), using the same strategy as used by Marsac et al. (2011) for Model VI. PHREEQC is a computer code based on an ion-association aqueous model, which was designed to perform speciation and saturation-index calculations in water. Thermodynamic constants are taken from NEA thermodynamic database (Guillaumont et al., 2003). Davies equation was used for activity coefficients calculation, being valid up to an ionic strength of $0.1 \mathrm{M}$.

A thorough description of Model VII can be found in Tipping et al. (1998; 2011). The model is a discrete binding site model which takes electrostatic interactions into account. Only the aqueous cation (e.g. $\mathrm{Pu}^{4+}$ ) and its first hydrolysis products (e.g. $\mathrm{PuOH}^{3+}$ ) are considered to bind to HA with the same binding constants. Eight sites are considered and divided into an equal number of type A sites (commonly associated with carboxylic functional groups) and type B sites (commonly associated with phenolic functional groups). There are $\mathrm{n}_{\mathrm{A}}$ $\left(m o l g^{-1}\right)$ type A sites and $n_{A} / 2$ type $B$ sites. An average value for $n_{A}\left(3.3 \times 10^{-3}\right.$ eq $\left.g^{-1}\right)$ was found by Tipping (1998) for various HA, leading to a PEC of $5.25 \times 10^{-3} \mathrm{eq} \mathrm{g}^{-1}$, which is relatively similar to the Aldrich HA used here and was not modified. Proton binding is 
217 described by the two median intrinsic protonation constants $\left(\mathrm{pK}_{\mathrm{A}}\right.$ or $\mathrm{pK} \mathrm{B}_{\mathrm{B}}$; negative decadic

218 logarithm of protonation constants $\mathrm{K}_{\mathrm{A}}$ or $\mathrm{K}_{\mathrm{B}}$ ) and two parameters defining the spread of the 219 protonation constants around the median $\left(\Delta \mathrm{pK}_{\mathrm{A}}\right.$ or $\left.\Delta \mathrm{pK}_{\mathrm{B}}\right)$. The intrinsic equilibrium constants 220 for cation binding are defined by two median constants (log $K_{M A}$ and $\left.\log K_{M B}\right)$, together with 221 parameters $\left(\Delta \mathrm{LK}_{1 \mathrm{~A}}\right.$ and $\left.\Delta \mathrm{LK}_{1 \mathrm{~B}}\right)$ that define the spread of the values around the medians.

222 However, satisfactory results are obtained by fixing $\Delta \mathrm{LK}_{1 \mathrm{~A}}=\Delta \mathrm{LK}_{1 \mathrm{~B}}=0$. The work of 223 Carbonaro and Di Toro (2007) showed that the relative binding strength of a metal cation with 224 monodentate ligands is the same as those for protons. This concept was applied to carboxylic and phenolic HA groups in Model VII by Tipping et al. (2011). It is assumed that

$$
\log \mathrm{K}_{\mathrm{MB}}=\log \mathrm{K}_{\mathrm{MA}} \cdot\left(\mathrm{pK_{ \textrm {B } }} / \mathrm{pK}_{\mathrm{A}}\right)
$$

227 which reduces the number of adjustable parameters necessary to describe metal complexation 228 by HA. A fraction of the type A and type B monodentate sites can form bi- $\left(\mathrm{f}_{\mathrm{bi}}\right)$ and tridentate $\left(f_{\text {tri }}\right)$ sites. The stability constants of these bi- and tridentate sites are defined by the sum of the $\log \mathrm{K}$ values of the monodentate sites of which they are constituted. A small part of the stability constants of multidentate groups are increased by the $\Delta \mathrm{LK}_{2}$ parameter, the so-called "strong binding site term" (Tipping, 1998). In Model VII, $\Delta \mathrm{LK}_{2}$ is commonly attributed to the participation of additional HA ligands in the complex, such as the nitrogen-containing groups.

234 However, Marsac et al. (2011) suggested that, in case of hard Lewis acids (e.g. trivalent 235 lanthanides), a high $\Delta \mathrm{LK}_{2}$ value might be attributed to a chelation effect. $\Delta \mathrm{LK}_{2}$ is also the 236 parameter of the HA site heterogeneity. An elevation of $\Delta \mathrm{LK}_{2}$ increases the range of the 237 stability constants covered by the HA sites, thus increasing the heterogeneity of HA regarding 238 cations binding. An electrical double layer, where only counter-ions can accumulate, is defined. The 240 double layer thickness is set by the Debye-Hückel parameter $\kappa=\left(3.29 \times 10^{9} \times I^{1 / 2}\right)^{-1}($ Appelo 241 and Postma, 2005), where I is the ionic strength ( $\left.\mathrm{mol} \mathrm{L}^{-1}\right)$. The distribution of ions between 
242 the diffuse layer and the bulk solution is calculated by a Donnan model. The electrostatic

243 correction is represented by an empirical equation which mimics the Boltzmann factor:

$$
\operatorname{Exp}(-z F \psi / R T)=\exp \left(-2 \mathrm{PzZ} \log _{10} \mathrm{I}\right)
$$

245 where $\mathrm{P}$ is an adjustable parameter, $\mathrm{z}$ is the ion charge, $\mathrm{Z}$ is the net humic acid charge (eq $\mathrm{g}^{-1}$ ), $246 \mathrm{I}$ is the ionic strength ( $\left.\mathrm{mol} \mathrm{L}^{-1}\right), \psi$ is the surface potential $(\mathrm{V}), \mathrm{T}$ is the temperature $(\mathrm{K}), \mathrm{F}$ is 247 the Faraday constant and $\mathrm{R}$ is the gas constant. In PHREEQC, the surface area (SA) is 248 required:

$$
\mathrm{SA}=\mathrm{ZF} \times\left(0.1174 \times \mathrm{I}^{1 / 2} \times \sinh (\mathrm{F} \psi / 2 \mathrm{RT})\right)^{-1}
$$

By combining eq. 2 and eq.3, a relationship between SA and $\mathrm{P}$ is obtained. For $\mathrm{I}=0.1$

$\mathrm{M}, \mathrm{P}=-196$, whatever $\mathrm{Z}$ is valued, $\left|\mathrm{PZ} \log _{10} \mathrm{I}\right|$ becomes low and the $\sinh$ can be approximated by a linear function (Taylor's approximation). Indeed, $\mathrm{R}^{2}=0.996$ is found when the sinh term versus $\mathrm{Z}$ is fitted with a linear function. The following equation is obtained:

$$
\left.\mathrm{SA}=\mathrm{F} \times\left(0.1174 \times \mathrm{I}^{1 / 2} \times \mathrm{P} \log _{10} \mathrm{I}\right)\right)^{-1}
$$

255 which depends only on the ionic strength. We found SA 20000 $\mathrm{m}^{2} \mathrm{~g}^{-1}$ for $\mathrm{I}=0.1 \mathrm{M}$. 256 Although rather unrealistic, such high surface area is the consequence of translating the 257 empirical electrostatic correction equation used in the initial version of Model VII into the 258 double layer theory. Such high SA were also used in different studies, where Model V 259 (Tipping and Hurley 1992) and VI were introduced into PHREEQC (Appelo and Postma, 260 2005; Liu et al., 2008; Marsac et al., 2011). To our knowledge there is no better solution at 261 present. Note that the present approximation is only valid for any $\mathrm{Z}$ when both $\left|\log _{10} \mathrm{I}\right|$ and $|\mathrm{P}|$ 262 are low. For lower I than $0.1 \mathrm{M}$ or more negative $\mathrm{P}$ values (e.g. -330 as in Model VI), the 263 linearization of the $\sinh$ function is only valid for a narrower range of $\mathrm{Z}$ values. It means that 264 SA depends also on the pH. In this case, Marsac et al. (2011) simply chose a value of SA in PHREEQC/Model VI that fitted best the simulated HA proton titration simulated with 
WHAM/Model VI, between pH 2 and 10. A summary of all Model VII parameters are given 267 in the supporting information (Table S2).

As can be deduced from the latter description of Model VII, the description of HA

269 binding properties is comparable with solid surface complexation modeling. Humic acid

270 conformation changes with the physico-chemical conditions are not explicitly described.

271 However, their impact on cation complexation might be included implicitly in the different

272 binding parameters used. The physical state of the humic, i.e. probably coagulated for $\mathrm{pH}<2$

273 in the present study or even voluntarily insolubilized (Weber et al., 2006), is not supposed to

274 impact the determination of cation-HA binding parameters for Model VII. It will be further 275 illustrated in the present study.

\subsection{Parameter estimation with PhreePlot}

PhreePlot (Kinniburgh and Cooper, 2009) contains an embedded version of

PHREEQC and is mainly used to produce certain types of high quality geochemical plots using PHREEQC such as pH-Eh diagrams, for instance. However, PhreePlot also includes a parameter optimization procedure, which fits automatically the model to the experimental 282 data by minimizing the weighted sum of squares of the residuals. A modified MarquardtLevenberg procedure (Powel, 1965) was applied, which provides incertitude on the estimated parameters. In the present study, PhreePlot was requested to fit $\log [\mathrm{Pu}]_{\mathrm{aq}}$ by optimizing $\log$ $\mathrm{K}_{\mathrm{MA}}(\mathrm{Pu}(\mathrm{IV})), \Delta \mathrm{LK}_{2}(\mathrm{Pu}(\mathrm{IV}))$ as well as the formation constant of polynuclear $\mathrm{Pu}(\mathrm{IV})$ species

286 with HA. Numeric tags can substitute numbers in the PHREEQC section of the PhreePlot 287 input file. In Model VII, every Pu(IV)-HA complexation constants being calculated from log $\mathrm{K}_{\mathrm{MA}}(\mathrm{Pu}(\mathrm{IV}))$ and $\Delta \mathrm{LK}_{2}(\mathrm{Pu}(\mathrm{IV}))$, a readable form of Model VII must be written for PhreePlot 289 using the keyword "numericTags" to make possible the automatic determination of optimizing log $\mathrm{K}_{\mathrm{MA}}(\mathrm{Pu}(\mathrm{IV}))$ and $\Delta \mathrm{LK}_{2}(\mathrm{Pu}(\mathrm{IV}))$ parameters. 


\subsection{Plutonium(IV) interaction with humic acid}

Fig. 1 shows the solubility of $\mathrm{Pu}(\mathrm{IV})$ as a function of $\mathrm{pH}$ calculated with PHREEQC

295 from the following equation (Guillaumont et al., 2003):

$\mathrm{PuO}_{2 \text { (am,hyd) }}+2 \mathrm{H}_{2} \mathrm{O}=\mathrm{Pu}^{4+}{ }_{(\mathrm{aq})}+4 \mathrm{OH}^{-} ; \log \mathrm{K}_{\mathrm{s}}=-58.33 \pm 0.52 \quad(\mathrm{I}=0)$

297 The $\mathrm{Pu}(\mathrm{IV})$ concentrations at equilibrium $\left([\mathrm{Pu}(\mathrm{IV})]_{\mathrm{aq}}\right)$ in the present $\mathrm{Pu}-\mathrm{HA}$ complexation experiments are below the solubility curve. Dotted lines represent the uncertainty on $\mathrm{Pu}(\mathrm{IV})$ solubility, as determined from the uncertainties of hydrolysis constants and solubility product.

Therefore, no precipitation or $\mathrm{Pu}(\mathrm{IV})$-colloids is expected. This statement might be, however, debatable at $\mathrm{pH}=3$ because here, $[\mathrm{Pu}(\mathrm{IV})]_{\mathrm{aq}}$ are higher than the minimum uncertainty limit of the $\mathrm{Pu}(\mathrm{IV})$ solubility.

$\mathrm{Pu}(\mathrm{IV})-\mathrm{HA}$ complexation data were first treated as follows:

$\mathrm{n} \mathrm{Pu}+\mathrm{HA}=\mathrm{Pu}_{\mathrm{n}} \mathrm{HA}$

$$
K_{\text {exp }}=\frac{\left[P u_{n} H A\right]}{[P u]_{e q}{ }^{n}[H A]}=\frac{[P u H A] / n}{[P u]_{e q}{ }^{n}[H A]}
$$

where $\mathrm{K}_{\mathrm{exp}}$ is a conditional constant, $[\mathrm{Pu}]_{\mathrm{eq}}\left(\mathrm{in} \mathrm{mol} \mathrm{L}^{-1}\right)$ and $[\mathrm{PuHA}]\left(\mathrm{mol} \mathrm{g}^{-1}\right.$ of $\left.\mathrm{HA}\right)$ denotes the experimentally determined concentrations of $\mathrm{Pu}$ in the filtrate and in the retentate, 308 respectively, and $\mathrm{n}$ is the stoichiometry of the reaction normalized to one HA site. [HA] is 309 defined here as the PEC (eq $\left.\mathrm{g}^{-1}\right)$ of HA, i.e. the total site concentration, because it is not 310 possible to determine precisely the free HA site concentration due to both HA site 311 heterogeneity and the lack of knowledge about $\mathrm{Pu}(\mathrm{IV})-\mathrm{HA}$ interaction. This implies that $\mathrm{n}$ and

$312 \mathrm{~K}_{\mathrm{exp}}$ are only estimates of the stoichiometry and conditional formation constants of reaction 6.

313 Applying some rearrangements to eq. 7, one obtains a Freundlich-type isotherm equation:

$314 \log \frac{[P u H A]}{[H A]}=\log K_{\exp }+\log n+n \log [P u]_{e q}$ 
Fig. 2 presents the amount of $\mathrm{Pu}(\mathrm{IV})$ complexed to $\mathrm{HA}$ (in $\mathrm{mol} \mathrm{eq}^{-1}$ ) as a function of

$316 \mathrm{Pu}(\mathrm{IV})$ equilibrium concentration ([Pu(IV) $\left.]_{\mathrm{eq}}\right)$, i.e. the $\mathrm{Pu}(\mathrm{IV})-\mathrm{HA}$ binding isotherm. The concentration of plutonium humic complexes ( $\mathrm{Pu}(\mathrm{IV})-\mathrm{HA})$ increases with $\mathrm{pH}$ due to the decrease of proton competition for HA binding groups in the complexation reaction. From low $\left(10^{-9} \mathrm{M}\right)$ to intermediate $\mathrm{Pu}$ concentrations $\left(10^{-8} \mathrm{M},[\mathrm{Pu}(\mathrm{IV})]_{\mathrm{eq}}\right)$, the slope of the log-log isotherm is with a value of 0.73 significantly below 1 (illustrated for $\mathrm{pH} 3$ in Fig. 2). This is explained with the heterogeneity of $\mathrm{HA}$ sites for $\mathrm{Pu}(\mathrm{IV})$ complexation. The latter $\mathrm{pH}$ and metal loading effects have been widely described for many cations complexation by humic substances, and a slope below 1 is commonly observed for cations binding to humic even at 324 low site occupancy (e.g. Benedetti et al., 1995). However, for $[\mathrm{Pu}(\mathrm{IV})]_{\mathrm{aq}}>10^{-8} \mathrm{M}$, the mean slope of the isotherm of all $\mathrm{pH}$ values drastically increases to a value of 3.5 (3.8 as illustrated at $\mathrm{pH}=3$; Fig. 2). At $\mathrm{pH}=3$, this observation might be firstly attributed to the precipitation of $\mathrm{Pu}(\mathrm{IV})$-(hydr)oxides or at least to formation of $\mathrm{Pu}(\mathrm{IV})$ eigencolloids because experimental $[\mathrm{Pu}(\mathrm{IV})]_{\mathrm{aq}}$ values are near to the $\mathrm{Pu}(\mathrm{IV})$ solubility limit. However, the same high slope (3.94) is observed at a more acidic $\mathrm{pH}$ value of 1.8 , where it is clear that $\mathrm{Pu}(\mathrm{IV})$ does not precipitate 330 in the range of $[\mathrm{Pu}(\mathrm{IV})]_{\mathrm{aq}}$ studied here. It is well established that $\mathrm{Pu}(\mathrm{IV})$ is the most stable $\mathrm{Pu}$ 331 redox state in the presence of HA even under anaerobic conditions (Marquardt et al., 2004; 332 Dardenne et al., 2009). Furthermore, the present experiments were performed in contact with 333 air preventing the formation of $\mathrm{Pu}(\mathrm{III})$. Therefore, the slope of the isotherm being larger than 3341 is not a result of oxidation state transformation during the experiment, but might be 335 attributed to the presence of $\mathrm{Pu}(\mathrm{IV})$ polynuclear species. Because $\mathrm{Pu}(\mathrm{IV})$ solubility was 336 determined by ultrafiltration at $3 \mathrm{kDa}$ (pore size: 1-2 nm; Neck and Kim, 2001) to separate $337 \mathrm{Pu}(\mathrm{IV})-\mathrm{HA}$ complexes from the solution, the increase of the amount of $\mathrm{Pu}(\mathrm{IV})$ in the HA 338 fraction of our experiments can only be attributed to polynuclear $\mathrm{Pu}(\mathrm{IV})$ species associated to 339 the HA colloids. Indeed, earlier studies showed no significant difference between $3 \mathrm{kDa}$ and 1 
$340 \mathrm{kDa}$ ultrafilter for the separation of $\mathrm{Pu}(\mathrm{IV})-\mathrm{HA}$ complexes. If we consider a linear binding

341 behavior of polynuclear $\mathrm{Pu}(\mathrm{IV})$ species to $\mathrm{HA}$, the slope of the isotherm equal to 3.5 suggests

342 the formation of $3: 1$ or 4:1 Pu-HA complexes, presuming a polynuclear $\mathrm{Pu}(\mathrm{IV})$ species binds

343 to one HA site. When considering the 4:1 stoichiometry, at $\mathrm{pH}=3$, a condition constant of $\log$

$344 \mathrm{~K}_{\exp }=27.3$ can be estimated for the humate complexation reaction (6). However, due to HA

345 heterogeneity, binding of polynuclear $\mathrm{Pu}(\mathrm{IV})$ species to HA might not be linear, and would

346 imply a higher degree of $\mathrm{Pu}(\mathrm{IV})$ polynucleation. This stoichiometry is actually more likely an

347 average value because a large variety of polynuclear species might be formed at the same time

348 with HA, as it has been observed by Walther et al. (2009), in solution under similar conditions, 349 but below the solubility limit.

\subsection{Modeling with PHREEQC/model VII}

The preceding interpretations are tested with the humic-ion binding model, Model VII.

Phreeplot was used to calibrate Pu-HA binding parameters in Model VII fitting the present experimental data. This automatic fitting procedure also provides the uncertainty of the determined parameters. The optimized model parameters are presented in Table 1 and are compared with the estimated values determined by Stockdale et al. (2011) that were used here as initial values for the fit. $\log \mathrm{K}_{\mathrm{MA}}$ (i.e. the main binding parameter) and $\Delta \mathrm{LK}_{2}$ (i.e. the strong sites binding parameter) were found equal to $3.9 \pm 0.2$ and $1.7 \pm 0.5$, respectively. These results are not significantly different from the estimated values of Stockdale et al. (2011) and validate the estimation method. For Th(IV), Tipping et al. (2011) have determined log

$361 \mathrm{~K}_{\mathrm{MA}}(\mathrm{Th}(\mathrm{IV}))=3.58$ and $\Delta \mathrm{LK}_{2}(\mathrm{Th}(\mathrm{IV}))=0.23$, which are slightly lower than the presently 362 determined values for $\mathrm{Pu}(\mathrm{IV})$. But when applying the uncertainties from the $\mathrm{Pu}(\mathrm{IV})$ fit on the 363 Th(IV) values, both data set can be regarded as very similar within the range of uncertainties.

364 The simulated results are also illustrated as binding isotherms in Fig. 3 (dotted lines), when 
considering only the binding of $\mathrm{Pu}(\mathrm{IV})$-monomers to HA. The model can reproduce relatively 366 well the results for $[\mathrm{Pu}(\mathrm{IV})]_{\mathrm{aq}}$ below approximately $10^{-8} \mathrm{M}$. Obviously, the model cannot reproduce the change in the slope of the binding isotherm at $[\mathrm{Pu}(\mathrm{IV})]_{\mathrm{aq}}$ higher than $10^{-8} \mathrm{M}$, for 368 the reasons explained before.

370 written as follows by Takao et al. (2012):

$371 \mathrm{a} \mathrm{RCOO}^{-}+\mathrm{b} \mathrm{An}{ }^{4+}+\mathrm{c} \mathrm{H}_{2} \mathrm{O}=(\mathrm{RCOO})_{\mathrm{a}} \mathrm{An}_{\mathrm{b}} \mathrm{O}_{\mathrm{c}} \mathrm{H}_{\mathrm{d}}+(\mathrm{c}+\mathrm{d}) \mathrm{H}^{+}$

$$
K_{\text {poly }}=\frac{\left[(R C O O)_{a} A n_{b} O_{c} H_{d}\right]\left[H^{+}\right]^{(c+d)}}{\left[R C O O^{-}\right]^{a}\left[A n^{4+}\right]^{b}}
$$

373 where $a, b, c$, and $d$ are, respectively, equal to $12,6,8$ and 4 in case of formate $(R=H, \log$ $374 \mathrm{~K}_{\text {poly }}=42.7$ at $\left.\mathrm{I}=0.62 \mathrm{M}\right)$ and acetate $\left(\mathrm{R}=\mathrm{CH}_{3}, \log \mathrm{K}_{\text {poly }}=52.0\right.$ at $\left.\mathrm{I}=0.66 \mathrm{M}\right)$, for $\mathrm{An}=\mathrm{Np}$. 375 In case of $\mathrm{Pu}(\mathrm{IV})-\mathrm{HA}$ complexation, the stoichiometry seems to be approximately 4:1, 376 according to the present experiments. The $\mathrm{pH}$ dependence of the reaction is, however, very 377 difficult to evaluate because of HA site heterogeneity, the competition between $\mathrm{Pu}(\mathrm{IV})$ and $\mathrm{H}^{+}$ 378 for these sites and the hydrolysis of $\mathrm{Pu}(\mathrm{IV})$ formed with HA. Furthermore, Walther et al. 379 (2009) observed a large variety of the number of $\mathrm{Pu}$ atoms in the polynuclear species. As 380 mentioned before, the stabilization of polynuclear $\mathrm{Pu}(\mathrm{IV})$ species by HA should probably be 381 described by a distribution of polynuclear $\mathrm{Pu}(\mathrm{IV})$ species. Unfortunately, it appears not 382 possible for the moment to provide a more precise description of the formation of polynuclear 383 Pu-HA species by modeling, because the distribution of the polynuclear species is unknown.

384 The modeling exercise in the present paper is based on several assumptions. Although it can 385 be regarded as a rough estimation of this complex system, it will help us as an illustration to 386 discuss the relevance of such polynuclear species under environmental conditions. Because $387 \mathrm{Pu}(\mathrm{OH})_{2}{ }^{2+}$ is the dominant species in solution (see Fig. S1) from which polynuclear 388 compounds are formed via edge sharing, the formation reaction of tetra-Pu(IV)-HA 389 complexes was introduced in Model VII as follows: 
Only the mono-carboxylic sites defined in Model VII were considered, which represent $43.5 \%$ of the total HA carboxylic groups because the fraction of bi- and tridentate sites is fixed. Indeed, the 4:1 stoichiometry of the complexes would not have been respected when considering the complexation of Pu-tetramer to bi- and tridentate HA sites as defined in Model VII. The logarithm of the formation constant of reaction (11) was found to be 31.4 \pm 0.4 . This value is higher than the conditional formation constant estimated by the slope analysis (e.g. 27.3 at $\mathrm{pH}=3$; Fig. 2) because, (i) the latter one did not take into account the HA sites occupancy by $\mathrm{Pu}$ and protons, and (ii) only $43.5 \%$ of HA sites are involved according to Model VII definition of monodentate sites. Although this tetramer complex presents a high 400 positive charge, it might be compensated by the overall HA negative charge. The 401 complexation of relatively highly charged polynuclear species to humics are generally 402 required to model data obtained in acidic condition: $\mathrm{Al}_{2}(\mathrm{OH})_{4}{ }^{4+}$ (Sutheimer and Cabaniss, 403 1997), $\mathrm{Fe}_{2} \mathrm{O}^{4+}$ (Gustafsson et al., 2007) or $\mathrm{Fe}_{3} \mathrm{O}_{2}{ }^{5+}$ (Marsac et al., 2013). Note that in the present model, the Pu-tetramer-HA formation reaction suggests HA sites as templates for bridge bonding between hydroxy-Pu(IV) ions, which is consistent with the previous trivalent cation-humics studies. The results of the fit are presented in Fig. 3. The model can reproduce the data at $\mathrm{pH} 1.8$ relatively well whereas more deviations are observed at $\mathrm{pH} 3$. By 408 increasing the $\mathrm{pH}$, the distribution of hydrolyzed polymeric An(IV) species increases (Walther et al., 2009). The deviation observed at $\mathrm{pH}=3$ might be a direct consequence of the strong simplification of the system in the model by introducing only one type of polynuclear $411 \mathrm{Pu}(\mathrm{IV})$ species. Nevertheless, considering such (over)simplification, this approach can reproduce the experimental results relatively well. 


\subsection{Comparison with An(IV)-HA binding data from literature}

Reiller et al. (2008) compiled and re-interpreted the An(IV)-HA (An = Th, U, Pu)

417 complexation data available in the literature. They recalculated conditional complexation

418 constants as follows:

$419 \mathrm{An}^{4+}+\mathrm{HA}=\mathrm{AnHA}$

${ }^{H A} \beta\left(A n^{4+}\right)=\frac{[A n H A]}{\left[A n^{4+}\right]_{a q}[H A]}$

421 where [HA] is calculated from the proton exchange capacity (eq $\mathrm{g}^{-1}$ ). The concentration of the $422 \mathrm{An}^{4+}$ aquo cation $\left[\mathrm{An}^{4+}\right]_{\mathrm{aq}}$ are very low and are calculated from the total aqueous $\mathrm{An}(\mathrm{IV})$ 423 concentration ([An(IV) $\left.]_{\mathrm{aq}}\right)$ measured experimentally and the hydrolysis constants $\left(\beta_{1, \mathrm{n}}\right)$ of the 424 considered An(IV):

$\left[A n^{4+}\right]_{a q}=[A n(I V)]_{a q} \times\left(1+\sum_{n=1}^{4} \frac{\beta_{1, n}}{\left[H^{+}\right]^{n}}\right)=[A n(I V)]_{a q} \alpha_{A n}$

426 The site reaction coefficient $\alpha_{\text {An }}$ considers all hydrolysis reactions of the $\mathrm{An}^{4+}$ cation. They

427 found a high consistency between all tetravalent actinides by only using the hydrolysis 428 constants of $\mathrm{U}(\mathrm{IV})$ for all An(IV) hydrolysis reactions and they derived the following 429 equation:

$430 \quad \log { }^{\mathrm{HA}} \beta\left(\mathrm{An}^{4+}\right)=(3.26 \pm 0.10) \mathrm{pH}+(0.14 \pm 0.67)$.

431 The present experimental results were recalculated with the approach of Reiller et al.

432 for $[\mathrm{Pu}(\mathrm{IV})]_{\mathrm{aq}}<10^{-8} \mathrm{M}$ (i.e. where $\mathrm{Pu}(\mathrm{IV})$ binds to HA as monomeric species) and are plotted 433 in Fig. 4 as well as the results of eq. (15) (Reiller et al., 2008) for different pH. The 434 consistency between the present $\log { }^{\mathrm{HA}} \beta\left(\mathrm{Pu}^{4+}\right)$ data for $[\mathrm{Pu}(\mathrm{IV})]_{\mathrm{aq}}<10^{-8} \mathrm{M}$ and eq. 15 shows 435 that our results are in excellent agreement with literature. In at least part of our experiments 436 (i.e. for $\mathrm{pH}<2$ ), $\mathrm{HA}$ has coagulated. This result suggests that the physical state of the humic 437 has no significant impact on its binding properties, which was already observed in earlier 438 studies for An(III) or Fe(III) (Kim et al., 1993; Weber et al., 2006). Note that because of the 
439 low solubility of $\mathrm{An}(\mathrm{IV})$, experiments performed at high $\mathrm{pH}$ had low $[\mathrm{An}(\mathrm{IV})]_{\text {tot. Therefore, }}$, 440 the slope of eq. (15) takes also into account, implicitly, the effect of low metal loading of HA. Simulations with PHREEQC/Model VII were performed as a function of the $\mathrm{pH}$ using

$44210 \mathrm{mg} / \mathrm{L}$ of $\mathrm{HA}$ and $[\mathrm{Pu}(\mathrm{IV})]_{\text {tot }} 10$ times below the solubility limit. Such conditions are 443 commonly investigated to avoid $\mathrm{An}(\mathrm{OH})_{4(\mathrm{am})}$ precipitation or colloid formation in the sample. 444 The contribution of $\mathrm{Pu}(\mathrm{IV})$ tetramer is also negligible. The results of the simulations were 445 recalculated according to eq. (13) - (14) and taking into account the default PEC value of HA in Model VII. These results are illustrated together with the results according to eq. (15) 447 (Reiller et al., 2008) in Fig. 4. Although Pu(IV)-HA binding parameters in Model VII were 448 calibrated only with our experimental results obtained under acidic conditions (i.e. $\mathrm{pH} \leq 3$ ), the evolution of $\log { }^{\mathrm{HA}} \beta\left(\mathrm{Pu}^{4+}\right)$ with $\mathrm{pH}$ is well described up to $\mathrm{pH}=7$, attributing to Model VII 450 some efficiency as a predictive tool. The uncertainty of Model VII parameters presently 451 determined (bold dotted lines) are comparable with the uncertainty of $\log { }^{\mathrm{HA}} \beta\left(\mathrm{An}^{4+}\right)$ 452 determined by Reiller et al. (2008). As mentioned earlier, only the binding of $\mathrm{Pu}^{4+}$ and $453 \mathrm{PuOH}^{3+}$ to HA were considered. This finding is opposed to the Charge Neutralization Model 454 (CNM), commonly used to describe actinides complexation by humic acids (Kim and 455 Czerwinski, 1996). This model requires the binding of several hydrolysis products of $\mathrm{Pu}(\mathrm{IV})$ 456 to HA to simulate the $\mathrm{pH}$ dependence of $\log { }^{\mathrm{HA}} \beta\left(\mathrm{Pu}^{4+}\right)$. However, the $\mathrm{CNM}$ does not take into 457 account the heterogeneity of HA and cannot reproduce the effect of the metal loading, for 458 instance. Model VII considers the presence of strong chelating sites in low amount. Due to the 459 low solubility of $\mathrm{PuO}_{2(\mathrm{am}, \mathrm{hyd})},[\mathrm{Pu}(\mathrm{IV})]_{\mathrm{aq}}$ becomes very low under near neutral conditions. 460 Therefore, in such conditions, $\mathrm{Pu}(\mathrm{IV})$ is considered to be complexed by chelating sites of HA. 461 It has been shown that chelating ligands can inhibit An(IV) hydrolysis (e.g. Jeanson et al., 462 2010) even under alkaline conditions. The description of $\mathrm{Pu}(\mathrm{IV})-\mathrm{HA}$ interaction provided by 463 Model VII might be considered as relatively consistent from the mechanistic point of view. 
464 Model VII underestimates $\log { }^{\mathrm{HA}} \beta\left(\mathrm{Pu}^{4+}\right)$ for $\mathrm{pH}>7$, suggesting that more hydrolyzed $\mathrm{Pu}(\mathrm{IV})$ 465 species, such as $\mathrm{Pu}(\mathrm{OH})_{2}{ }^{2+}$, might have to be considered as species bound to HA. However, 466 preliminary tests (not presented here) showed that $\mathrm{Pu}(\mathrm{OH})_{2}{ }^{2+}$ Model VII parameters had to be 467 optimized independently from $\mathrm{PuOH}^{3+}$, which lead to an increase in the number of adjustable 468 parameters. Furthermore, a binding isotherm up to high loading cannot be obtained

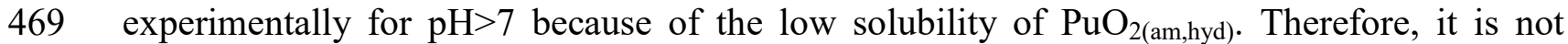
470 possible to constrain $\mathrm{Log} \mathrm{K}_{\mathrm{MA}}$ and $\Delta \mathrm{LK}_{2}$ for $\mathrm{Pu}(\mathrm{OH})_{2}{ }^{2+}$ independently. Predictive modeling 471 of $\mathrm{Pu}(\mathrm{IV})$ solubility in the presence of HA would give very different results depending on the 472 choice of the couple $\log \mathrm{K}_{\mathrm{MA}} / \Delta \mathrm{LK}_{2}$. Furthermore, it does not seem very clear if additional 473 parameters (i.e. the complexation of more hydrolyzed $\mathrm{Pu}(\mathrm{IV})$ monomers) have to be 474 considered in the calculations. Indeed, cation complexation constants with HA multidentate 475 sites in Model VII are subjected to a large uncertainty. For instance, the uncertainty associated 476 with the formation of a bidentate complex is twice the sum of the corresponding monodentate 477 ones. The strong sites are additionally subjected to the incertitude associated to $\Delta \mathrm{LK}_{2}$. This 478 can somewhat be seen, for instance on figure 4: at low $\mathrm{pH}$, the simulation was performed at 479 higher $[\mathrm{Pu}(\mathrm{IV})]_{\text {tot }}$ than at high $\mathrm{pH}$. Therefore, at low $\mathrm{pH}$, the incertitude on $\log { }^{\mathrm{HA}} \beta\left(\mathrm{Pu}^{4+}\right)$ is 480 almost not visible on figure 4 because $\mathrm{Pu}(\mathrm{IV})$ speciation with $\mathrm{HA}$ is dominated by lower 481 denticity sites than at higher $\mathrm{pH}$, where the strong HA multidentate sites are dominant. A 482 slight modification of already existing parameters describing the strong sites in Model VII 483 might improve significantly the simulation for An(IV) complexation to HA without 484 considering additional parameters. However, the present study does not aim at revising Model 485 VII. Therefore, the present discussion will be limited to $\mathrm{pH}<7$, where only the complexation 486 of $\mathrm{Pu}^{4+}$ and $\mathrm{PuOH}^{3+}$ binding to $\mathrm{HA}$ can reproduce relatively well the experimental results. 


\subsection{Relevance of poly-Pu(IV)-HA species under circumneutral conditions}

Dardenne et al. (2009) have studied the Pu(IV)-HA formation by XAFS in a humic491 rich groundwater $\left(\sim 70 \mathrm{mgC} \mathrm{L}^{-1}\right)$ at $\mathrm{pH} \sim 7$ and a Pu concentration of $1.4 \times 10^{-4} \mathrm{M}$. In presence of $492 \mathrm{HA}$, this $\mathrm{Pu}(\mathrm{IV})$ concentration is approximately $10^{6}$ times higher than $\mathrm{Pu}(\mathrm{IV})$ solubility limit 493 in $0.1 \mathrm{M} \mathrm{NaCl}$ aqueous solution at $\mathrm{pH}=7$. In the experiment, a precipitation of potential $494 \mathrm{Pu}(\mathrm{IV})$-(hydr)oxide was not observed and the good quality of the data confirms that a 495 significant fraction of the $\mathrm{Pu}(\mathrm{IV})$ remained in solution. Indeed, to be able to record an Extended X-ray Absorption Fine Structure (EXAFS) spectrum up to $\mathrm{k}=11 \AA^{-1}, \mathrm{Pu}(\mathrm{IV})$ concentrations of $\sim 100 \mathrm{ppm}$ are typically required in the solution, which corresponds to $\sim 10^{-4}$ $\mathrm{M}$ of $\mathrm{Pu}(\mathrm{IV})$. The EXAFS showed a significant $\mathrm{Pu}-\mathrm{Pu}$ signal. Furthermore, the $\mathrm{Pu}$ L3-edge XANES (X-ray Absorption Near Edge Structure) was very similar to aqueous Pu(IV) (i.e. in a

500 solution at $\mathrm{pH}=0$ ) and differed strongly from solid $\mathrm{PuO}_{2 \text { (am,hyd) }}$ or from colloidal $\mathrm{Pu}(\mathrm{IV}$ ) in 501 solution (Walther et al., 2009). From the mechanistic point of view, it might be possible to consider these entities as polynuclear complexes with humic rather than precipitated nanophases. In neutral to alkaline $\mathrm{pH}$ conditions, when the solution is in contact with solid

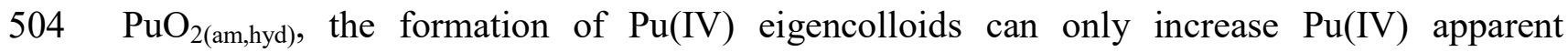
505 solubility up to $10^{-8.3 \pm 0.5} \mathrm{M}$ (Neck et al., 2007). These results evidenced that natural organic 506 matter can inhibit the precipitation of $\mathrm{PuO}_{2 \text { (am,hyd) }}$ by the formation of small polynuclear $507 \mathrm{Pu}(\mathrm{IV})$ humate species. Although there is no available systematic solubility study of $\mathrm{Pu}(\mathrm{IV})$ in 508 the presence of $\mathrm{HA}$, the large amount of $\mathrm{Pu}$ remaining in solution in the experiments of 509 Dardenne et al. (2009) suggests also that HA can enhance Pu apparent solubility. This might 510 also impact $\mathrm{Pu}$ mobility in organic-rich environments, provided that a significant amount of 511 Pu-HA does not aggregate.

The $\mathrm{Pu}(\mathrm{IV})$ apparent solubility in presence of HA was simulated with 513 PHREEQC/Model VII for $2<\mathrm{pH}<7$, i.e. in a range of $\mathrm{pH}$ conditions where Model VII gave 
514 satisfactory results, in a $0.1 \mathrm{M} \mathrm{NaCl}$ solution containing $140 \mathrm{mg} \mathrm{L}^{-1}$ of HA. This [HA] 515 corresponds to $70 \mathrm{mg} \mathrm{L}^{-1}$ of dissolved organic carbon (DOC), considering that carbon 516 represents 50 wt.\% of HA. These conditions reproduce roughly the Gorleben groundwater 517 (Marquardt et al., 2004) and they were investigated here as an illustration rather than in sense 518 of a prediction. Aqueous $\mathrm{Pu}(\mathrm{IV})$ and $\mathrm{Pu}(\mathrm{IV})$-HA species were considered as dissolved species. 519 Results are presented in Fig. 5. When considering only the formation of monomeric Pu(IV)520 HA species, HA can significantly enhance $\mathrm{Pu}(\mathrm{IV})$ apparent solubility for $\mathrm{pH}>2.5$. At $\mathrm{pH}=7$, 521 the apparent solubility in presence of HA is underestimated by more than 3 orders of 522 magnitude, compared with the sample studied by XAFS by Dardenne et al. (2009). Note also 523 that the precipitation of metallic (hydr)oxides in the presence of HA might lead to highly 524 amorphous or nanometric (hydr)oxides with an enhanced solubility. This was the case, for 525 instance, for Fe(III) whose (hydr)oxides formed in the presence of HA had a higher solubility 526 than ferrihydrite, an amorphous Fe(III)-hydroxide (Weber et al., 2006; Marsac et al., 2013). 527 However, the increase of Fe(III) solubility in presence of HA did not exceed one order of 528 magnitude. When considering additionally the formation of polynuclear $\mathrm{Pu}(\mathrm{IV})$-HA species, $529 \mathrm{Pu}(\mathrm{IV})$ apparent solubility increases in presence of HA by 1.5 log units at $\mathrm{pH}=3$. The 530 arbitrarily chosen $\mathrm{Pu}(\mathrm{IV})$ tetramer to illustrate the present experimental results between $\mathrm{pH} 1$ 531 and 3 has no impact for $\mathrm{pH}>4$ and cannot explain the XAFS results of Dardenne et al. (2009). 532 Actually, the fact that the $\mathrm{Pu}(\mathrm{IV})$ tetramer has only an impact in conditions quite similar to the 533 present experiments is rather comforting because its occurrence at $\mathrm{pH}>5$ would have been 534 highly questionable. Nevertheless, these simulations show that the stabilization of a more 535 hydrolyzed $\mathrm{Pu}_{\mathrm{n}}(\mathrm{OH})_{\mathrm{m}}$ species than $\mathrm{Pu}_{4}(\mathrm{OH})_{8}{ }^{8+}$ by $\mathrm{HA}$ should be considered in the model to 536 produce simulations consistent with spectroscopy. To our best knowledge, the only experimental An(IV) solubility data in the presence 538 of organic matter were performed with U(IV) in the presence of carbonates (Cachoir et al., 
2003; Delécaut et al., 2004). Such data are relevant for performance assessment of nuclear waste disposal but it is difficult to determine precisely which chemical mechanisms hide behind the observed behavior. Under these conditions, U(IV) can easily be oxidized to U(VI) and carbonates can compete with organic matter. Indeed, Reiller et al. (2008) analyzed the data by geochemical speciation modeling and discussed the factors that could have an influence on uranium concentration in the HA-containing solution. The finally presented simulated results, although very promising, still underestimated U solubility data. However, the stabilization of polynuclear U(IV)-HA species could not be tested because there was no clear evidence of such species in the literature. By comparison with the present results for $\mathrm{Pu}(\mathrm{IV})$, the formation of polynuclear actinide(IV)-HA might be an alternative explanation for the deviation observed between experimental and modeling results. However, it is very difficult to estimate precisely the thermodynamic parameters of such reaction yet, especially under near neutral $\mathrm{pH}$ conditions.

\section{CONCLUSION}

The present study on $\mathrm{Pu}(\mathrm{IV})$ humate complexation at $\mathrm{pH}<3$ yields evidence for the complexation of both mono- and polynuclear $\mathrm{Pu}(\mathrm{IV})$ species to HA, at conditions where no $\mathrm{Pu}(\mathrm{IV})$ precipitation is expected. Model VII is used to simulate $\mathrm{Pu}(\mathrm{IV})$ monomers binding to HA. The simulations are consistent with other tetravalent actinides-HA binding data from literature (Reiller et al., 2008). The stabilization of a $\mathrm{Pu}$ tetramer $\left(\mathrm{Pu}_{4}(\mathrm{OH})_{8}{ }^{8+}\right)$ by $\mathrm{HA}$ is proposed to illustrate $\mathrm{Pu}(\mathrm{IV})-\mathrm{HA}$ interaction in conditions where polynuclear $\mathrm{Pu}(\mathrm{IV})-\mathrm{HA}$ species are formed. Although a robust model considering both the formation of mono- and polynuclear $\mathrm{Pu}(\mathrm{IV})$ complexes with $\mathrm{HA}$ cannot be derived from the present and previous studies, such polynuclear species are expected to have an impact under relevant conditions in the environment. They significantly increase the $\mathrm{Pu}(\mathrm{IV})$ apparent solubility due to HA 
564 complexation, more than by humate complexation of monomeric $\mathrm{Pu}(\mathrm{IV})$ species. Due to their

565 similar chemical properties, comparable mechanisms are also expected for other tetravalent 566 actinides, such as U(VI) and $\mathrm{Np}$ (IV). Such a mechanism of humate or fulvate complexation 567 strongly supports a transport of An(IV) as a humic colloid-borne species as observed in 568 migration experiments (Artinger et al., 2003a,b). Therefore, further studies should be 569 dedicated to the colloidal stability of An(IV)-HA (i.e. mono- and polynuclear) complexes. 570 More generally, the stabilization of polynuclear cations by HA seems to be a relevant 571 mechanisms at least for cations presenting a high tendency for hydrolysis such as An(IV), 572 Al(III) (Browne and Driscoll, 1993; Sutheimer and Cabaniss, 1997) or Fe(III) (Gustafsson et 573 al., 2007; Karlsson and Persson, 2010). This might impact on the fate of these elements in the 574 environment but might also affect other elements through the competition for organic matter 575 binding sites.

\section{Acknowledgements.}

578 We would like to thank the 'German Ministry of Economy and Technology' (Projekt 02 E 57993095 and 02 E 1579653') for financial support. We thank the three anonymous reviewers 580 and the associate editor, Dr. Marc Norman, for their helpful comments.

\section{References}

Appelo C. and Postma D. (2005) Geochemistry, groundwater and pollution. second ed. Taylor \& Francis, New York, p. 595.

Artinger R., Buckau G., Zeh P., Gereadts K., Vancluysen J., Maes A. and Kim J. I. (2003a) Humic colloid mediated transport of tetravalent actinides and technetium. Radiochim. Acta 91, 743-750. Humic colloid mediated transport of plutonium studied by column experiments. 
Internal report, institut for nuclear waste disposal, Forschungszentrum Karlsruhe, Karlsruhe, Germany.

592

593

594

595

596

597

598

599

600

601

602

603

604

605

606

607

608

609

610

611

612

613

614

615

616

617

618

619

Avena M. J., Vermeer A. W. P. and Koopal L. K. (1999) Volume and structure of humic acids studied by viscometry $\mathrm{pH}$ and electrolyte concentration effects. Colloids and Surfaces A 151, 213-224.

Benedetti M. F., Milne C. J., Kinniburgh D. G., van Riemsdijk W. H. and Koopal L. K. (1995) Metal-ion binding to humic substances: application of the non-ideal competitive adsorption model. Environ. Sci. Technol. 29, 446-457.

Browne B. A. and Driscoll C. T. (1993) pH dependent binding of aluminum by a fulvic acid. Environ. Sci. Technol. 27, 915-922.

Cachoir C., Lemmens K., Van den Berghe S. and Van Iseghem P. (2003) $\mathrm{UO}_{2}$ dissolution in Boom Clay conditions. J. Nucl. Mater. 321, 49-59.

Carbonaro R.F. and Di Toro D.M. (2007) Linear free energy relationships for metal-ligand complexation: Monodentate binding to negatively-charged oxygen donor atoms. Geochim. Cosmochim. Acta 71, 3958-3968.

Choppin G. R. (2003) Actinide speciation in the environment. Radiochim. Acta 91, 645-650.

Cohen D. (1961) The absorption spectra of plutonium ion in perchloric acid solutions. $J$. Inorg. Nucl. Chem. 18, 211-218.

Dardenne K., Seibert A. , Denecke M. A. and Marquardt C. M. (2009) Plutonium(III,IV,VI) speciation in Gorleben groundwater using XAFS. Radiochim. Acta 97, 91-97.

Delécaut G., Maes N., De Canniere P. and Wang L. (2004) Effect of reducing agents on the uranium concentration above uranium(IV) amorphous precipitate in Boom Clay pore water. Radiochim. Acta 92, 545-550.

Guillaumont R., Fanghänel Th., Fuger J., Grenthe I., Neck V., Palmer D.A. and Rand M.H. (2003) Update on the chemical thermodynamics of uranium, neptunium, plutonium, americium and technetium. OECD/NEA Data Bank, Eds., Chemical Thermodynamics vol. 5, Elsevier, Amsterdam.

Gustafsson J. P., Persson I., Kleja D. B. and van Schaik J. W. J. (2007) Binding of iron(III) to organic soils: EXAFS spectroscopy and chemical equilibrium modeling. Environ. Sci. Technol. 41, 1232-1237. 
Hellman H., Laitinen R. S., Kaila L., Jalonen J. E., Hietapelto V. K., Jokela J., Sarpola A. T. and Rämö J. H. (2006) Identification of hydrolysis products of $\mathrm{FeCl}_{3} \cdot 6 \mathrm{H}_{2} \mathrm{O}$ by ESI-MS. J. Mass Spectrom. 41, 1421-1429.

Jeanson A., Ferrand M., Funke H., Hennig C., Moisy P., Solari P. L., Vidaud C. and Auwer C.D. (2010) The role of transferrin in actinide(IV) uptake: comparison with iron(III). Chem. Eur. J. 16, 1378-1387.

Karlsson T. and Persson P. (2010) Coordination chemistry and hydrolysis of Fe(III) in a peat humic acid studies by X-ray absorption spectroscopy. Geochim. Cosmochim. Acta 74, $30-40$.

Kim J. I., Rhee D. S., Wimmer H., Buckau G. and Klenze R. (1993) Complexation of trivalent actinide ions $\left(\mathrm{Am}^{3+}, \mathrm{Cm}^{3+}\right)$ with humic acid: A comparison of different experimental methods. Radiochim. Acta 62, 35-43.

Kim J. I. and Buckau G. (1988) Report RCM 02188, Institut für Radiochemie der TU 182 München. 183.

Kim J. I. and Czerwinski K. R. (1996) Complexation of metal ions with humic acid: metal ion charge neutralization model. Radiochim. Acta 73, 5-10.

Kim J. I., Buckau G., Li G. H., Duschner H. and Psarros N. (1990) Characterization of humic acid and fulvic acids from Gorleben groundwater. Fresenius J. Anal. Chem. 338, 245252.

Kinniburgh D. G. and Cooper D. M. (2009) PhreePlot: Creating graphical output with PHREEQC. $<$ http://www.phreeplot.org>.

Knope K. E. and Soderholm L. (2013) Plutonium(IV) cluster with a hexanuclear $\left[\mathrm{Pu}_{6}(\mathrm{OH})_{4} \mathrm{O}_{4}\right]^{12+}$ core. Inorg. Chem., in press. DOI: $10.1021 / \mathrm{ic} 4007185$

Kretzschmar R. and Schäfer T. (2005) Metal retention and transport on colloidal particles in the environment. Element 1, 205-210.

Liu D. J., Bruggeman C. and Maes N. (2008) The influence of natural organic matter on the speciation and solubility of Eu in Boom Clay porewater. Radiochim. Acta 96, 711-720.

Marquardt C. M., Seibert A., Artinger R., Denecke M. A., Kuczewski B., Schild D. and Fanghänel Th. (2004) The redox behaviour of plutonium in humic rich groundwater. Radiochim. Acta 92, 617-623. 
Marsac R., Davranche M., Gruau G., Bouhnik-Le Coz M and Dia A. (2011) An improved description of the interactions between rare earth elements and humic acids by modelling. Geochim. Cosmochim. Acta 75, 5625-5637.

Marsac R., Davranche M., Gruau G., Dia A., Pédrot M., Bouhnik-Le Coz M. and Briant N. (2013) Iron competitive effect on REE binding to organic matter: implications with regards to REE patterns in waters. Chem. Geol. 342, 119-127.

Milne C. J., Kinniburgh D. G. and Tipping E. (2001) Generic NICA-Donnan Model parameters for proton binding by humic substances. Environ. Sci. Technol. 35, 20492059.

Milne C. J., Kinniburgh D. G., Van Riemsdijk W. H. and Tipping E. (2003) Generic NICADonnan Model parameters for metal-ion binding by humic substances. Environ. Sci. Technol. 37, 958-971.

Neck V. and Kim J. I. (2001) Solubility and hydrolysis of tetravalent actinides. Radiochim. Acta 89, 1-16.

Neck V., Altmaier M., Seibert A., Yun J.I., Marquardt C.M. and Fanghänel Th. (2007) Solubility and redox reactions of $\mathrm{Pu}(\mathrm{IV})$ hydrous oxide: Evidence for the formation of $\mathrm{PuO}_{2+\mathrm{x}}$ (s, hyd). Radiochim. Acta 95, 193-207.

Parkhurst D. L. and Appelo C. A. J. (1999) User's guide to PHREEQC (Version 2) - a computer program for speciation, batch reaction, one-dimensional transport and inverse geochemical calculation. Water-resources Investigation Report 99-4259, USGS, Denver, Colorado, p. 312.

Pourret O., Davranche M., Gruau G. and Dia A. (2007) Rare earth complexation by humic acid. Chem. Geol. 243, 128-141.

Powell M. J. D. (1965) A method for minimizing a sum of squares of non-linear functions without calculating derivatives. The Computer Journal 7, 303-307. Also see VA05 in the HSL Archive, ftp://ftp.numerical.rl.ac.uk/pub/hsl_catalogs/archive/catalog.pdf.

Reiller P., Evans N. D. M. and Szabó G. (2008) Complexation parameters for the actinides(IV)-humic acid system: a search for consistency and application to laboratory and field observations. Radiochim. Acta 96, 345-358.

Saito T., Nagasaki S., Tanaka S. and Koopal L. K. (2005) Electrostatic interactions model for ion binding to humic substances. Colloids and Surfaces A 265, 104-113. 
681

682

683

684

685

686

687

688

689

690

691

692

693

694

695

696

697

698

699

700

701

702

703

704

705

706

707

708

709

Sarpola A. T., Hietapelto V. K., Jalonen J. E., Jokela J. and Rämö J. H. (2013) Comparison of hydrolysis products of $\mathrm{AlCl}_{3} \cdot 6 \mathrm{H}_{2} \mathrm{O}$ in different concentrations by electrospray ionization time of flight mass spectrometer (ESI TOF MS). Intern. J. Environ. Anal. Chem. 86(13), 1007-1018.

Sasaki T., Aoyama S., Yoshida H., Kulyako Y., Samsonov M., Kobayashi T., Takagi I., Miyasoedov B. and Moriyama H. (2012) Apparent formation constants of Pu(IV) and Th(IV) with humic acids determined by solvent extraction method. Radiochim. Acta 100, 737-745.

Seibert A., Mansel A., Marquardt C. M., Keller H., Kratz J. V. and Trautmann N. (2001) Complexation behaviour of neptunium with humic acid. Radiochim. Acta 89, 505-510

Stockdale A., Bryana N. D. and Loft S. (2011) Estimation of Model VII humic binding constants for $\mathrm{Pd}^{2+}, \mathrm{Sn}^{2+}, \mathrm{U}^{4+}, \mathrm{NpO}_{2}^{2+}, \mathrm{Pu}^{4+}$ and $\mathrm{PuO}_{2}^{2+}$. J. Environ. Monit. 13, 29462950.

Sutheimer S. H. and Cabaniss S. E. (1997) Aluminum binding to humic substances determined by high performance. Geochim. Cosmochim Acta 61(1), 1-9.

Szabó G., Guczi J., Reiller P., Miyajima T. and Bulman R. A. (2010) Effect of ionic strength on complexation of $\mathrm{Pu}(\mathrm{IV})$ with humic acid. Radiochim. Acta 98, 13-18.

Takao K., Takao S., Scheinost A. C., Bernhard G. and Hennig C. (2012) Formation of soluble hexanuclear neptunium(IV) nanoclusters in aqueous solution: Growth termination of actinide(IV) hydrous oxides by carboxylates. Inorg. Chem. 51, 1336-1344.

Tipping E. (1998) Humic ion-binding model VI: an improved description of the interactions of protons and metal ions with humic substances. Aquat. Geochem. 4, 3-48.

Tipping E. and Hurley M. A. (1992) A unifying model of cation binding by humic substances. Geochim. Cosmochim. Acta 56, 3627-3641.

Tipping E., Lofts S. and Sonke J. (2011) Humic ion-binding Model VII: a revised parameterisation of cation-binding by humic substances. Environ. Chem. 8, 225-235.

Walther C., Fuss M. and Büchner S. (2008) Formation and hydrolysis of polynuclear Th(IV) complexes - a nano-electrospray mass spectrometry study. Radiochim. Acta 96, 411425. 
710 Walther C., Rothe J., Brendebach B., Fuss M., Altmaier M., Marquardt C. M., Büchner S., 711 Cho H.-R., Yun J.-I. and Seibert A. (2009) New insights in the formation processes of Pu(IV) colloids. Radiochim. Acta 97, 199-207.

713 Weber T., Allard T., Tipping E. and Benedetti M. (2006) Modelling iron binding to organic 714 matter. Environ. Sci. Technol. 40, 7488-7493.

715 
718 Table 1. $\mathrm{Pu}(\mathrm{IV})-\mathrm{HA}$ binding parameters in Model VII $\left(\log \mathrm{K}_{\mathrm{MA}}\right.$ and $\left.\Delta \mathrm{LK}_{2}\right)$ presently 719 determined. Estimated values by Stockdale et al. (2011) and fitted parameters for Th(IV)-HA 720 complexation (Tipping et al., 2011) are also shown for comparison.

721 Figure 1. Comparison between $\mathrm{Pu}(\mathrm{IV})$ concentration determined experimentally at 722 equilibrium in the presence of $\mathrm{HA}$ at $\mathrm{pH}=1.8,2.5$ and $3\left([\mathrm{Pu}]_{\mathrm{tot}} \sim 610^{-8} \mathrm{M}, 0.025<[\mathrm{HA}]<25 \mathrm{mg}\right.$ $\left.723 \mathrm{~L}^{-1}\right)$ and $\mathrm{Pu}(\mathrm{IV})$ solubility limit calculated from $\mathrm{Pu}(\mathrm{IV})$ hydrolysis and solubility product 724 given in Guillaumont et al. (2003) (plain line) with the corresponding incertitude (dashed 725 lines), in $0.1 \mathrm{M}$ of $\mathrm{NaClO}_{4}$.

726 Figure 2. $\mathrm{Pu}(\mathrm{IV})$ binding to $\mathrm{HA}$ as function of $\log [\mathrm{Pu}(\mathrm{IV})]_{\mathrm{aq}}$ at $\mathrm{pH} 1.8,2.5$ and 3. A "break" 727 in the binding isotherm is observed and is illustrated at $\mathrm{pH} 3$ by fitting the data with two linear 728 functions, $[\mathrm{HA}]=0.025-25 \mathrm{mg} / \mathrm{L}, \mathrm{I}=0.1 \mathrm{M} \mathrm{NaClO}_{4}$, contact time $=1$ week, Ultrafiltration $729 \quad(1 \mathrm{kDa})$.

730 Figure 3. Comparison between experimental and modeling results of $\mathrm{Pu}(\mathrm{IV})$-HA binding 731 considering or not the stabilization of $\mathrm{Pu}(\mathrm{IV})$ tetramer by $\mathrm{HA}$.

732 Figure 4. Evolution $\mathrm{An}^{4+}-\mathrm{HA}$ conditional stability constant versus $\mathrm{pH}$ as calculated from eq. 73315 (Reiller et al. 2008; solid line within the incertitude presented as dashed lines). The present 734 experimental data (grey squares) and simulated results with Model VII (bold line) are also presented for comparison, associated with the incertitude on Model VII parameters (bold dotted lines.

737 Figure 5. Simulated $\mathrm{Pu}(\mathrm{IV})$ solubility versus $\mathrm{pH}$ in a $0.1 \mathrm{M}$ of $\mathrm{NaCl}$ solution containing $738140 \mathrm{mg} \mathrm{L}^{-1}$ of HA or no HA. The experimental condition studied by XAFS (Dardenne et al., 739 2009), where polynuclear Pu(IV)-HA species were evidenced, is also shown for comparison. 


\begin{tabular}{cccc} 
& $\begin{array}{c}\mathrm{Pu}(\mathrm{IV}) \\
\text { (present study) }\end{array}$ & $\begin{array}{c}\mathrm{Pu}(\mathrm{IV}) \\
\text { (estimated) }\end{array}$ & $\mathrm{Th}(\mathrm{IV})$ \\
\hline $\log \mathrm{K}_{\mathrm{MA}}$ & $3.9 \pm 0.2$ & 4.08 & 3.58 \\
$\Delta \mathrm{LK}_{2}$ & $1.7 \pm 0.5$ & 1.85 & 0.23 \\
\hline
\end{tabular}

743

Table 1

744 


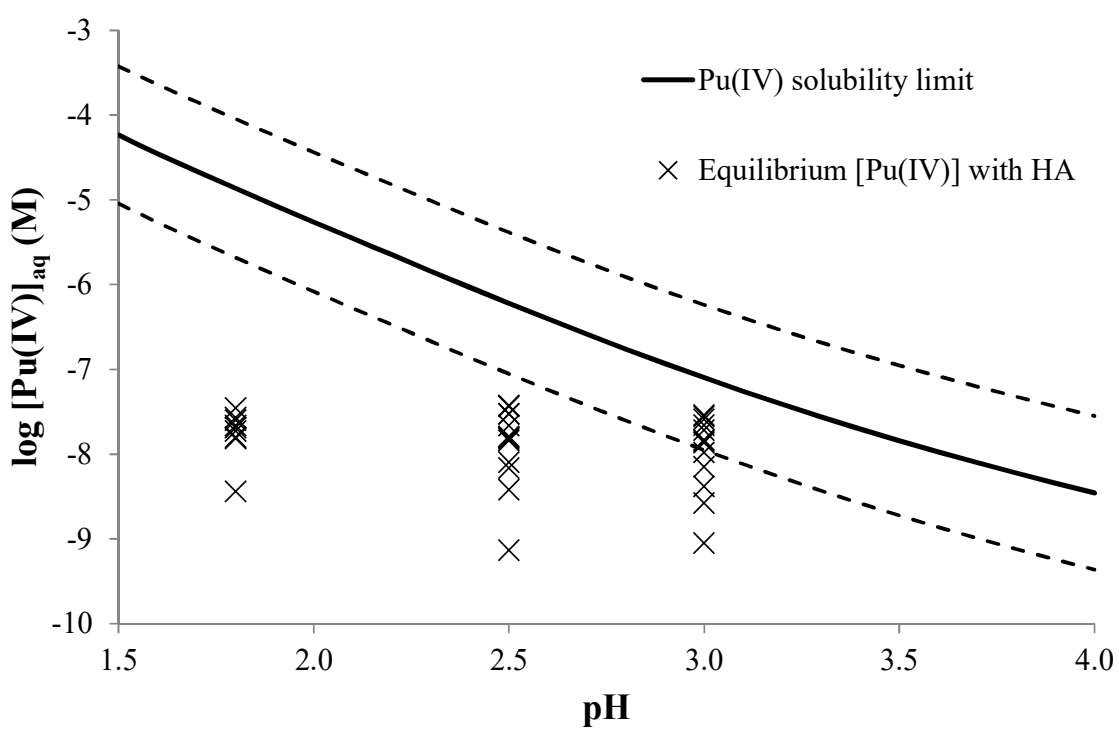

745

746

Figure 1

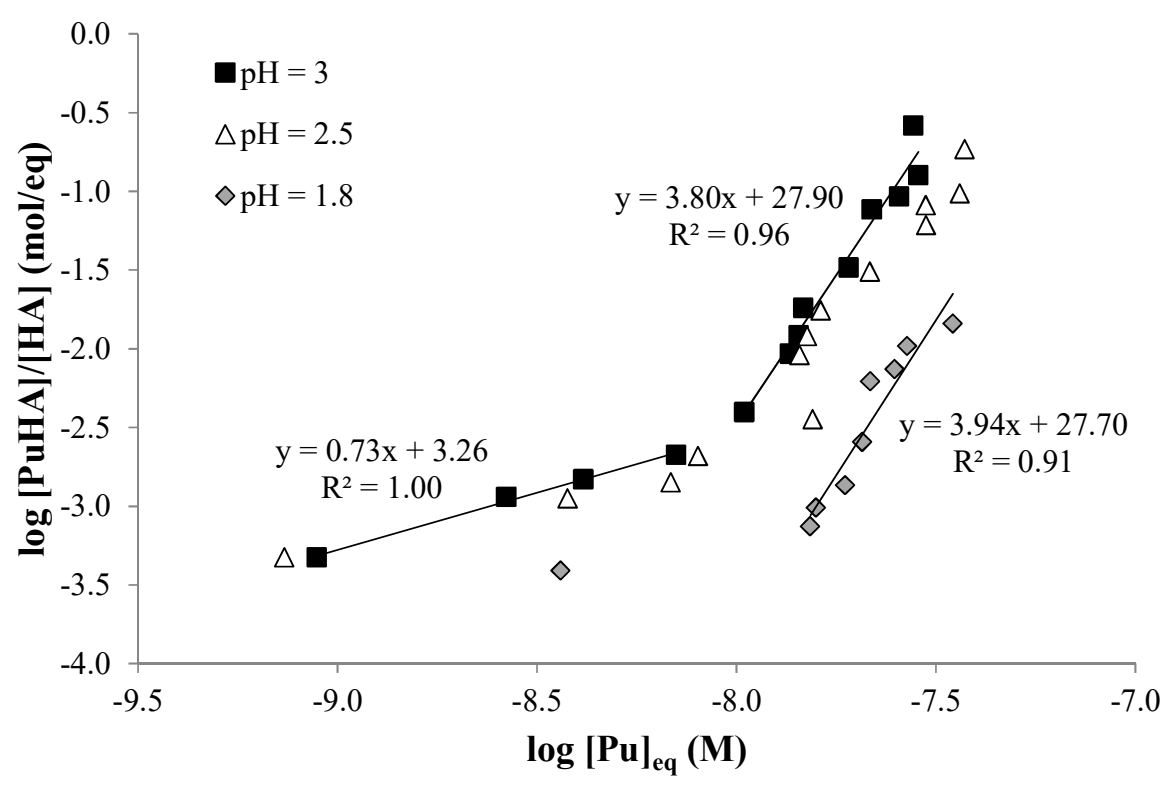

Figure 2 

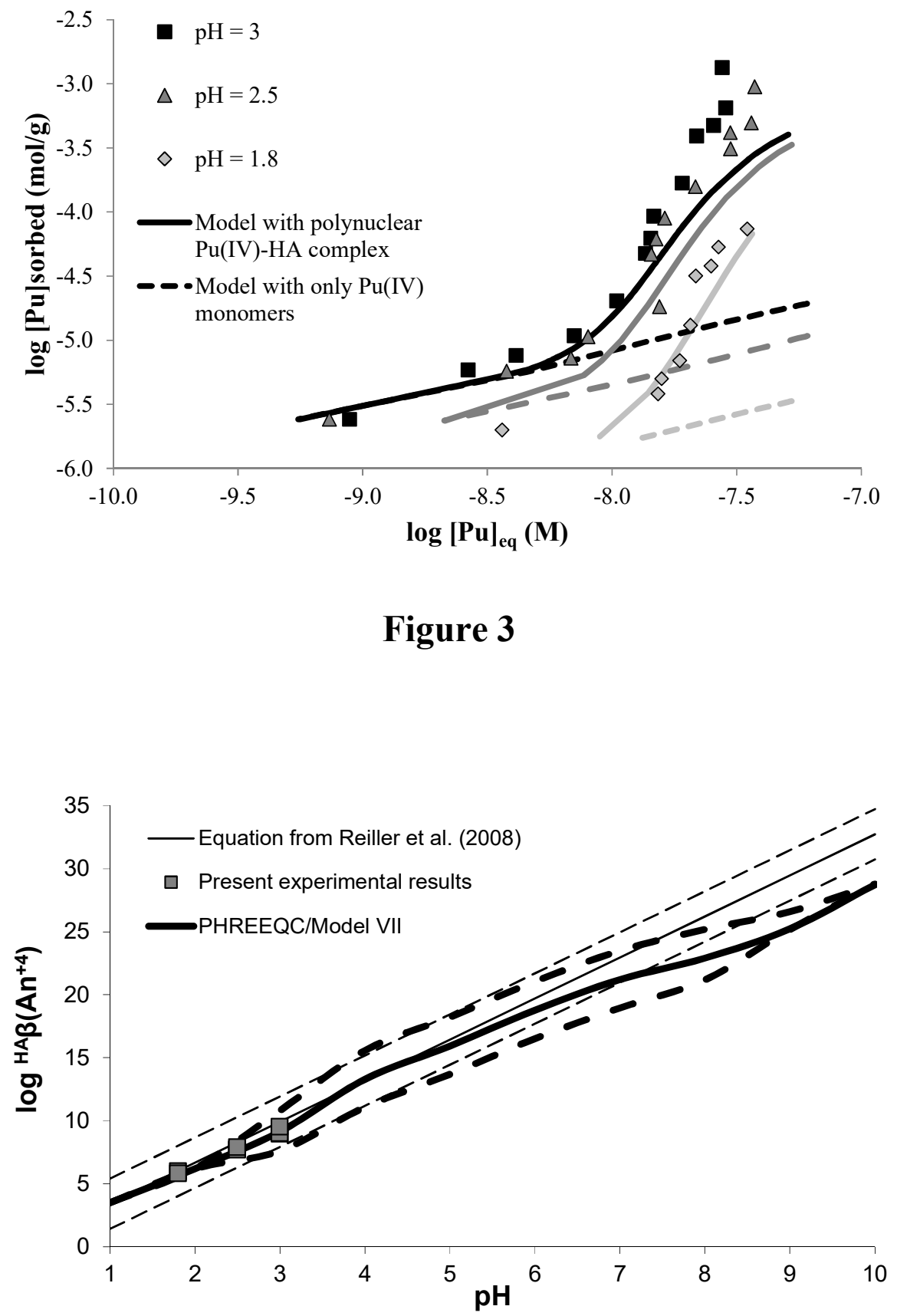


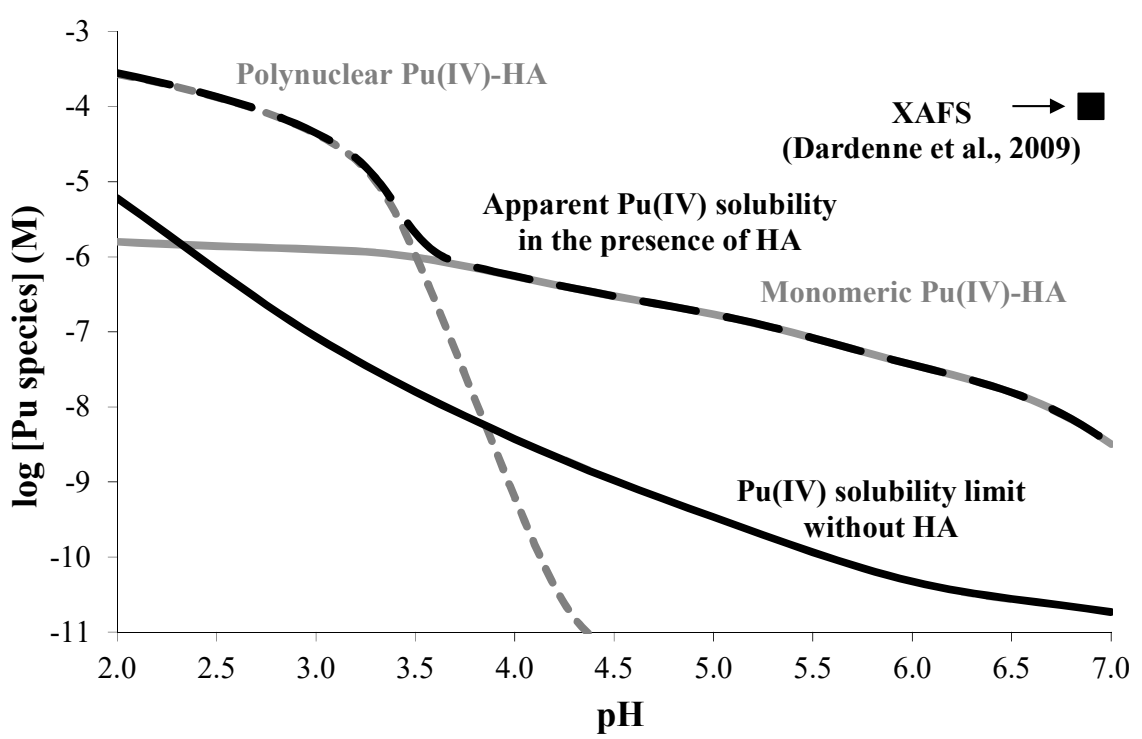

757

Figure 5

758 